\title{
Effects of Treadmill Exercise on Platelet Functions and Blood Coagulating Activities in Healthy Men
}

\author{
Naoki Taniguchi, M.D., Hirohiko Furui, M.D., \\ Kazunobu Yamauchi, M.D., and Iwao Sotobata, M.D.
}

\section{SUMMARY}

The effects of treadmill exercise (up to $85 \%$ of the predicted maximum heart rate) on platelet functions and coagulating activities were studied in 26 normal men. Blood sampling for the measurements were performed from the antecubital vein at rest, at $3,6,9$, and 12 min during exercise, immediately postexercise, and at 6 and $30 \mathrm{~min}$ after exercise. Measurements for blood analysis included the following: platelet sensitivity and percent aggregation to ADP, platelet counts, plasma thromboxane $\mathrm{B}_{2}$ and 6-keto-prostaglandin $F_{1 \alpha}$ levels, plasma epinephrine and norepinephrine levels, plasma fibrinogen level, activity of plasma antithrombin III, and of plasma factors VIII, IX, XI, and XII.

No significant changes were induced by dynamic leg exercise in platelet sensitivities and the maximum and 3-min percent aggregation. The platelet counts increased during exercise in plateletrich plasma without a significant change in that in whole blood. During exercise, plasma thromboxane $B_{2}$ levels showed a tendency to increase, while plasma 6-keto-prostaglandin $F_{1 \alpha}$ levels to decrease. Plasma epinephrine levels showed a tendency to increase and norepinephrine levels increased during exercise. Among coagulating factors, factor VIII activities and fibrinogen levels increased without altering activities of factors IX, XI, and XII. Antithrombin III activities also increased during exercise. In spite of significant changes in several coagulating factors, prothrombin time and partial thromboplastin time were not influenced by exercise.

In conclusion, dynamic leg exercise of a moderate to high intensity produced a significantly elevated plasma level of factor VIII, fibrinogen, antithrombin III, and catccholamines without affecting the hemostatic balance in normal subjects. Nagoya.

From the First Department of Internal Medicine, School of Medicine, Nagoya University,

Address for reprint: Naoki Taniguchi, M.D., First Department of Internal Medicine, School of Medicine, Nagoya University, 65 Tsurumai-cho, Showa-ku, Nagoya 466, Japan.

Received for publication August 5, 1983. 


\section{Additional Indexing Words:}

Treadmill exercise stress testings Platelet aggregation

Thromboxane $\mathrm{B}_{2}$ 6-keto-prostaglandin $\mathrm{F}_{1 \alpha} \quad$ Coagulating activities

T has been suggested that the disturbed dynamic balance among platelet function, coagulating activities and fibrinolysis may be a factor in the pathogenesis of atherosclerosis ${ }^{1,2)}$ and that platelets may play a part in atherogenesis and initiate arterial thrombosis by aggregation or by activating the coagulating factors. Effects of exercise on platelet functions, coagulating activities and fibrinolysis have been studied with isometric or dynamic exercise by many researchers. ${ }^{3-13}$ The alternation in platelet functions and coagulating activities during exercise was greater in patients with coronary artery disease than in normal subjects and was suggested to play a part in occurrence of angina pectoris and myocardial infarction by exercise. ${ }^{3,14}$ Recently, the mechanisms of arachidonic acid metabolism have been clarified in platelets as well as in the endothelial cells of vessel walls, and prostaglandins derived from arachidonic acid such as thromboxane $\mathrm{A}_{2}{ }^{15)}$ and prostacyclin ${ }^{16), 17)}$ were found to be responsible for the control of platelet aggregation and vasoconstriction. Much attention has been paid to the role of prostaglandins in thrombotic conditions or during exercise. ${ }^{18)-20)}$ However, the effects of exercise on platelet functions have not previously been studied in parallel with changes in blood coagulability, catecholamines, and prostaglandins.

In the present study, a systematic investigation was performed on normal subjects to clarify (1) what changes in platelet functions, prostanoids, catecholamines, and coagulating activities are induced by treadmill exercise, and (2) what the mechanism to maintain the hemostatic balance is.

\section{Materials AND Methods}

The materials consisted of 26 healthy male volunteers who had abstained from any medication for 2 weeks before the study. They ranged in age from 21 to 41 years with an average of $28.1( \pm 4.1)$ years. According to the modified Bruce's protocol, ${ }^{21)}$ multistage treadmill exercise testing was performed to the target heart rate $(85 \%$ of the predicted maximum heart rate). The testing was initiated at least 2 hours after a light lunch in the afternoon. Avoiding stagnation, blood sampling was obtained from the antecubital vein at rest immediately before exercise, at $3,6,9$, and 12 min during exercise, immediately postexercise, and at 6 and $30 \mathrm{~min}$ after the exercise.

Nine $\mathrm{ml}$ of blood was aspirated into a polypropyrene tube containing $1 \mathrm{ml}$ 
of $3.8 \%$ of trisodium citrate. Blood samples were immediately centrifuged at $800 \mathrm{rpm}$ for $10 \mathrm{~min}$ at room temperature, and $2 \mathrm{ml}$ of citrated platelet-rich plasma (PRP) was obtained as a supernatant. Residual samples were centrifuged at 3,000 rpm for $20 \mathrm{~min}$, and then $3 \mathrm{ml}$ of the supernatant was collected as platelet-poor plasma (PPP). According to the optical density method (O.D. method) ${ }^{22), 23)}$ using PRP and PPP, platelet aggregation studies were performed. ADP of $4,2,1$, and $0.5 \mu \mathrm{M}$ was used as an aggregating agent. Aggregation curves were analysed to obtain the 3-min and maximum percent aggregation. Furthermore, the minimum ADP concentration $\left(2^{-\mathbf{n}} \mu \mathrm{M}\right)$ to induce a biphasic aggregation curve was determined. The absolute value of the exponent (n) was defined as an index of platelet sensitivity to ADP. Counting platelets in PRP and citrated whole blood were made microscopically.

Five $\mathrm{ml}$ of blood was aspirated into a polypropyrene tube containing $4.5 \mathrm{mM}$ EDTA and $20 \mu \mathrm{M}$ aspirin. Samples were centrifuged at $3,000 \mathrm{rpm}$ for $20 \mathrm{~min}$ at $4^{\circ} \mathrm{C}$ to produce platelet-poor plasma for prostanoid assay. Radioimmunoassay for thromboxane $\mathrm{B}_{2}$ and 6-keto-prostaglandin $\mathrm{F}_{\mathbf{1}^{\alpha}}$ was performed after extraction from the plasma with ethyl acetate and resuspension in $100 \mathrm{mM}$ phosphate buffer ( $\mathrm{pH} 7.4$ ) containing $0.1 \%$ gelatin. ${ }^{24}$

Ten $\mathrm{ml}$ of blood for the determination of catecholamine levels were drawn into a polypropyrene tube containing $4.5 \mathrm{mM}$ EDTA. Samples were centrifuged at $3,000 \mathrm{rpm}$ for $20 \mathrm{~min}$ at $4^{\circ} \mathrm{C}$ to produce platelet-poor plasma. Plasma epinephrine and norepinephrine levels were estimated according to the trihydroxyindol method described by von Euler et $\mathrm{al}^{25)}$ and Mori ${ }^{26)}$ using high-speed liquid chromatography.

Using residual citrated PPP, measurement of prothrombin time, partial thromboplastin time, and activities of factors VIII, IX, XI, and XII was made by the one-stage method which electronically measures the rate of changes in optical density. Biological activities of factors VIII, IX, XI, and XII were determined according to the methods of Hardisty, ${ }^{27)}$ Rapaport, ${ }^{28}$ Horowitz ${ }^{291}$ and Loeliger ${ }^{301}$ respectively. Fibrinogen levels were determined by the single radial immunodiffusion method, and the biological activity of antithrombin III was determined by the quantichrom assay.

Paired $t$ test was used for statistical comparisons. A $p$ value of less than $0.05 \%$ was considered significant.

\section{ReSULTS}

(A) Cardiovascular response to treadmill exercise

The mean duration for treadmill exercise was $13.2( \pm 0.3)$ min, standard 
error. The mean of heart rate, systolic blood pressure, and pressure-rate product at the peak of exercise was $159( \pm 2) / \mathrm{min}, 165( \pm 4) \mathrm{mmHg}$, and 262 $( \pm 8)$, respectively.

(B) Platelet functions and coagulabilities

The mean \pm standard error of the measurements obtained was summarized in Tables I,II, and III.

Table I. Changes in Platelet Aggregation, Platelet Count, and Platelet-Related Prostaglandins

\begin{tabular}{|c|c|c|c|c|c|c|c|c|}
\hline & \multicolumn{5}{|c|}{ during exercise } & \multirow{2}{*}{$\begin{array}{l}\text { immedi- } \\
\text { ately } \\
\text { after } \\
\text { exercise }\end{array}$} & \multicolumn{2}{|c|}{ after exercise } \\
\hline & at rest & $3 \mathrm{~min}$ & $6 \stackrel{\mathrm{at}}{\mathrm{min}}$ & $9 \mathrm{~min}$ & $12 \mathrm{~min}$ & & $6 \stackrel{\text { at }}{\mathrm{min}}$ & $30 \mathrm{~min}$ \\
\hline \multirow{4}{*}{$\begin{array}{l}\text { Percentage of } \\
\text { maximum } \\
\text { platelet } \\
\text { aggregation } \\
(\%)\end{array}$} & $\begin{array}{r}73.2 \\
\pm 3.3\end{array}$ & & $\begin{array}{r}70.3 \\
\pm 3.6\end{array}$ & & $\begin{array}{r}71.5 \\
\pm 4.9\end{array}$ & $\begin{array}{r}68.0 \\
\pm 3.7\end{array}$ & $\begin{array}{r}68.9 \\
\pm 2.8\end{array}$ & $\begin{array}{r}71.3 \\
\pm 4.2\end{array}$ \\
\hline & $\begin{array}{r}58.3 \\
\pm 6.4\end{array}$ & & $\begin{array}{r}51.0 \\
\pm 5.5\end{array}$ & & $\begin{array}{r}63.0 \\
\pm 7.8\end{array}$ & $\begin{array}{r}58.6 \\
\pm 6.4\end{array}$ & $\begin{array}{r}56.5 \\
\pm 5.7\end{array}$ & $\begin{array}{r}56.5 \\
\pm 5.8\end{array}$ \\
\hline & $\begin{array}{r}31.5 \\
\pm 4.7\end{array}$ & & $\begin{array}{r}34.2 \\
\pm 4.8\end{array}$ & & $\begin{array}{r}37.5 \\
\pm 4.4\end{array}$ & $\begin{array}{r}35.8 \\
\pm 5.2\end{array}$ & $\begin{array}{r}33.3 \\
\pm 4.1\end{array}$ & $\begin{array}{r}31.1 \\
\pm 3.1\end{array}$ \\
\hline & $\begin{array}{r}16.7 \\
\pm 2.0\end{array}$ & & $\begin{array}{r}20.5 \\
\pm 3.2\end{array}$ & & $\begin{array}{r}22.5 \\
\pm 2.5\end{array}$ & $\begin{array}{r}17.0 \\
\pm 2.2\end{array}$ & $\begin{array}{r}16.9 \\
\pm 2.3\end{array}$ & $\begin{array}{r}18.2 \\
\pm 2.8\end{array}$ \\
\hline Platelet sensitivity & $\begin{array}{l}-1.09 \\
\pm 0.20\end{array}$ & & $\begin{array}{l}-1.09 \\
\pm 0.23\end{array}$ & & $\begin{array}{l}-0.88 \\
\pm 0.32\end{array}$ & $\begin{array}{l}-1.05 \\
\pm 0.25\end{array}$ & $\begin{array}{l}-1.09 \\
\pm 0.21\end{array}$ & $\begin{array}{l}-1.18 \\
\pm 0.18\end{array}$ \\
\hline $\begin{array}{l}\text { Platelet counts in cit- } \\
\text { rated PRP }\left(\times 10^{4} / \mathrm{ml}\right)\end{array}$ & $\begin{array}{r}28.5 \\
\pm 1.7\end{array}$ & $\begin{array}{r}34.3 \\
\pm 2.9 *\end{array}$ & $\begin{array}{l}31.4 \\
\pm 2.7 *\end{array}$ & $\begin{array}{r}32.5 \\
\pm 3.3\end{array}$ & $\begin{array}{l}30.8 \\
\pm 3.2 * *\end{array}$ & $\begin{array}{l}34.3 \\
\pm 2.1 * *\end{array}$ & $\begin{array}{r}28.6 \\
\pm 2.1\end{array}$ & $\begin{array}{r}25.7 \\
\pm 1.8\end{array}$ \\
\hline $\begin{array}{l}\text { Platelet counts in cit- } \\
\text { rated whole blood } \\
\qquad\left(\times 10^{4} / \mathrm{ml}\right)\end{array}$ & $\begin{array}{r}18.6 \\
\pm 1.4\end{array}$ & $\begin{array}{r}17.3 \\
+0.9\end{array}$ & $\begin{array}{r}18.3 \\
\pm 1.5\end{array}$ & $\begin{array}{r}18.5 \\
\pm 2.0\end{array}$ & $\begin{array}{r}18.4 \\
\pm 3.9\end{array}$ & $\begin{array}{r}19.7 \\
\pm 1.4\end{array}$ & $\begin{array}{r}19.1 \\
\pm 1.3\end{array}$ & $\begin{array}{r}17.1 \\
\pm 1.1\end{array}$ \\
\hline $\begin{array}{l}\text { Plasma thromboxane } \\
\mathrm{B}_{2} \\
(\mathrm{pg} / \mathrm{ml})\end{array}$ & $\begin{array}{c}80 \\
\pm 17\end{array}$ & & $\begin{array}{l}118 \\
\pm 27\end{array}$ & & $\begin{array}{l}80 \\
\pm 31\end{array}$ & $\begin{array}{l}118 \\
\pm 21\end{array}$ & $\begin{array}{l}160 \\
\pm 50\end{array}$ & $\begin{array}{l}118 \\
\pm 27\end{array}$ \\
\hline $\begin{array}{l}\text { Plasma 6-keto-PG } F_{1 \alpha} \\
(\mathrm{ng} / \mathrm{ml})\end{array}$ & $\begin{array}{r}1.12 \\
\pm 0.28\end{array}$ & & $\begin{array}{r}1.08 \\
\pm 0.21\end{array}$ & & $\begin{array}{r}1.13 \\
\pm 0.28\end{array}$ & $\begin{array}{r}1.00 \\
\pm 0.17\end{array}$ & $\begin{array}{r}0.95 \\
\pm 0.19\end{array}$ & $\begin{array}{r}1.34 \\
\pm 0.36\end{array}$ \\
\hline
\end{tabular}

Values are presented as mean \pm standard errors.

${ }^{*} \mathrm{p}<0.05$, ** $\mathrm{p}<0.025$, *** $\mathrm{p}<0.01$, **** $\mathrm{p}<0.005$ in comparison with values obtained before exercise.

Table II. Changes in Plasma Levels of Catecholamines

\begin{tabular}{|c|c|c|c|c|c|c|c|c|}
\hline & \multicolumn{5}{|c|}{ during exercise } & \multirow{2}{*}{$\begin{array}{l}\text { immedi- } \\
\text { ately } \\
\text { after } \\
\text { exercise }\end{array}$} & \multicolumn{2}{|c|}{ after exercise } \\
\hline & $\begin{array}{l}\text { at } \\
\text { rest }\end{array}$ & $3 \stackrel{\text { at }}{\mathrm{min}}$ & $\begin{array}{l}\text { at } \\
6 \mathrm{~min}\end{array}$ & $9 \stackrel{\text { at }}{\mathrm{min}}$ & $12 \mathrm{~min}$ & & at $\mathrm{min}$ & $30 \stackrel{\text { at }}{\mathrm{min}}$ \\
\hline $\begin{array}{l}\text { Plasma epinephrine } \\
\qquad(\mathrm{pg} / \mathrm{ml})\end{array}$ & $\begin{array}{l}75 \pm \\
23\end{array}$ & $\begin{array}{l}80 \pm \\
25\end{array}$ & $\begin{array}{l}94 \pm \\
23\end{array}$ & $\begin{array}{l}139 \pm \\
27^{*}\end{array}$ & $\begin{array}{l}60 \pm \\
38\end{array}$ & $\frac{130 \pm}{25}$ & $\begin{array}{l}53 \pm \\
17\end{array}$ & $\begin{array}{l}51 \pm \\
13\end{array}$ \\
\hline $\begin{array}{l}\text { Plasma norepinephrine } \\
\qquad(\mathrm{pg} / \mathrm{ml})\end{array}$ & $\begin{array}{c}184 \pm \\
28\end{array}$ & $\begin{array}{l}356 \pm \\
68^{* * *}\end{array}$ & $\begin{array}{l}379 \pm \\
54^{* * * * *}\end{array}$ & $\begin{array}{l}583 \pm \\
139 * * *\end{array}$ & $\begin{array}{l}482 \pm \\
144\end{array}$ & $\begin{array}{l}678 \pm \\
135^{* * * *}\end{array}$ & $\begin{array}{c}216 \pm \\
46\end{array}$ & $\begin{array}{c}147 \pm \\
27\end{array}$ \\
\hline
\end{tabular}

Values are presented as mean \pm standard errors.

${ }^{*} \mathrm{p}<0.05, * * \mathrm{p}<0.025, * * * \mathrm{p}<0.01,{ }^{* * * *} \mathrm{p}<0.005$ in comparison with values obtained before exercise. 
Table III. Changes in Blood Coagulability

\begin{tabular}{|c|c|c|c|c|c|c|c|c|}
\hline & \multicolumn{5}{|c|}{ during exercise } & \multirow{2}{*}{$\begin{array}{l}\text { immedi- } \\
\text { ately } \\
\text { after } \\
\text { exercise }\end{array}$} & \multicolumn{2}{|c|}{ after exercise } \\
\hline & $\begin{array}{l}\text { at } \\
\text { rest }\end{array}$ & $3 \mathrm{~min}$ & $6 \mathrm{~min}$ & $9 \stackrel{\text { at }}{\mathrm{min}}$ & $12 \mathrm{~min}$ & & $6 \stackrel{\text { at }}{\mathrm{min}}$ & $30 \stackrel{\mathrm{min}}{\mathrm{at}}$ \\
\hline $\begin{array}{l}\text { Activity of factor VIII } \\
(\%)\end{array}$ & $\frac{81 \pm}{6}$ & $\frac{86 \pm}{5}$ & $\begin{array}{c}96 \pm \\
5^{*}\end{array}$ & $\begin{array}{c}86 \pm \\
9\end{array}$ & & $\frac{103 \pm}{6 * * *}$ & $\frac{91 \pm}{6}$ & $88 \pm$ \\
\hline Activity of factor IX & $111 \pm$ & $119 \pm$ & $\begin{array}{c}107 \pm \\
6\end{array}$ & $\begin{array}{l}116 \pm \\
10\end{array}$ & & $117 \pm$ & $\frac{119 \pm}{8}$ & $\begin{array}{c}116 \pm \\
9\end{array}$ \\
\hline Activity of factor XI & $\begin{array}{c}136 \pm \\
9\end{array}$ & $\begin{array}{l}170 \pm \\
15\end{array}$ & $\begin{array}{c}156 \pm \\
17\end{array}$ & $\frac{159 \pm}{16}$ & & $\begin{array}{c}135 \pm \\
11\end{array}$ & $135 \pm$ & $\begin{array}{c}133 \pm \\
10\end{array}$ \\
\hline $\begin{array}{l}\text { Activity of factor XII } \\
\qquad \%)\end{array}$ & $\begin{array}{c}121 \pm \\
10\end{array}$ & $\begin{array}{c}113 \pm \\
10\end{array}$ & $\begin{array}{c}120 \pm \\
10\end{array}$ & $119 \pm$ & & $124 \pm$ & $\frac{126 \pm}{9}$ & $\begin{array}{l}123 \pm \\
10\end{array}$ \\
\hline $\begin{array}{l}\text { Plasma fibrinogen } \\
(\mathrm{mg} / \mathrm{dl})\end{array}$ & $\begin{array}{c}248 \pm \\
9\end{array}$ & $263 \pm$ & $258 \pm$ & $\frac{263 \pm}{12}$ & $\begin{array}{l}253 \pm \\
17 * *\end{array}$ & $\begin{array}{l}268 \pm \\
10^{* * * *}\end{array}$ & $\begin{array}{c}254 \pm \\
10\end{array}$ & $\begin{array}{c}244 \pm \\
9\end{array}$ \\
\hline $\begin{array}{l}\text { Activity of antithrombin } \\
\text { III }\end{array}$ & $\frac{104 \pm}{4}$ & $111 \pm$ & $\frac{110 \pm}{4 * * * *}$ & $112 \pm$ & $\begin{array}{r}115 \pm \\
6^{*}\end{array}$ & $\frac{115 \pm}{4^{* * * * *}}$ & $107 \pm$ & $\frac{100 \pm}{4}$ \\
\hline Prothrombin time & $\begin{array}{c}104 \pm \\
2\end{array}$ & $\frac{104 \pm}{2}$ & $\frac{104 \pm}{2}$ & $\frac{103 \pm}{2}$ & & $103 \pm$ & $\frac{104 \pm}{1}$ & $\frac{105 \pm}{2}$ \\
\hline $\begin{array}{l}\text { Partial thromboplastin } \\
\text { time }\end{array}$ & $\frac{98 \pm}{6}$ & $91 \pm$ & $\frac{94 \pm}{7}$ & $\frac{93 \pm}{8}$ & & $\frac{94 \pm}{4}$ & $\frac{92 \pm}{5} \pm$ & $\frac{92 \pm}{4}$ \\
\hline
\end{tabular}

Values are presented as mean \pm standard errors.

${ }^{*} \mathrm{p}<0.05, * * \mathrm{p}<0.025, * * * \mathrm{p}<0.01, * * * * \mathrm{p}<0.005$ in comparison with values obtained before exercise.

\section{(1) Platelet aggregation}

No significant changes were induced by exercise in the 3-min and maximum percent aggregation with $4,2,1$, and $0.5 \mu \mathrm{M}$ of ADP (Fig, 1) and also in platelet sensitivity. Platelet counts in PRP increased from $28.5( \pm 1.7)$ / $\mathrm{mm}^{3}$ at rest to $34.3( \pm 2.1) / \mathrm{mm}^{3}$ immediately after exercise $(\mathrm{p}<0.025)$, but those in whole blood were not significantly influenced by exercise (Fig. 2).

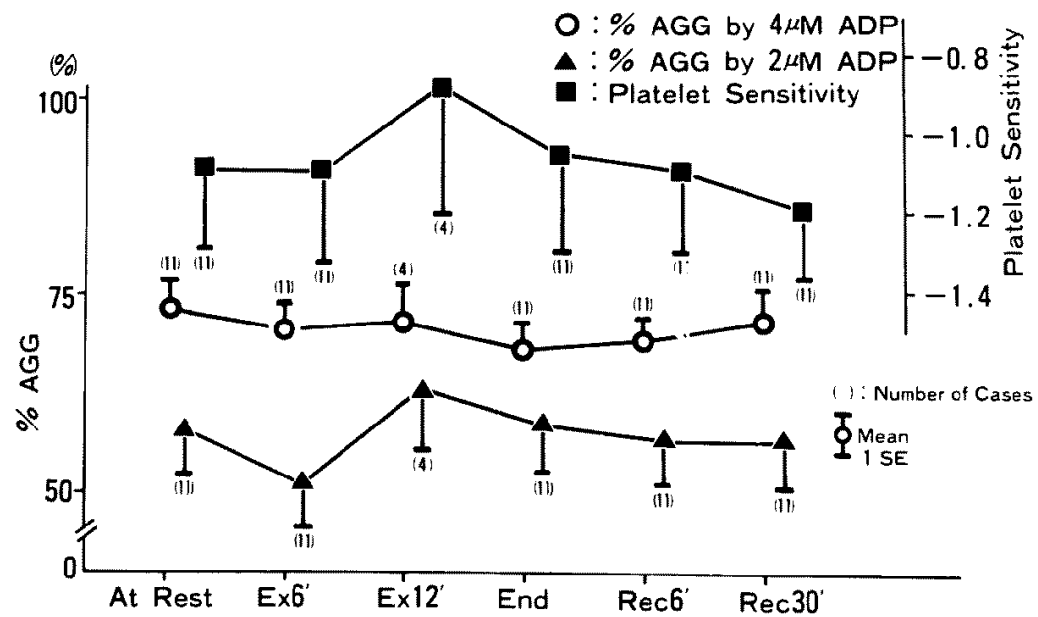

Fig. 1. Changes in platelet sensitivity and max percent aggregation. 


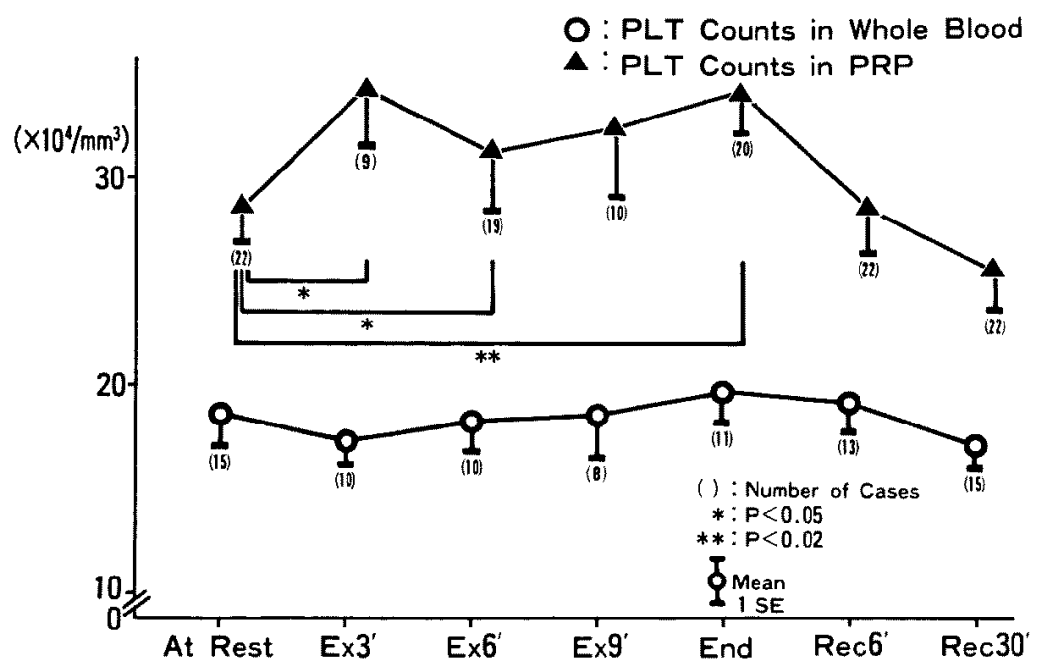

Fig. 2. Changes in platelet counts in PRP and citrated whole blood.

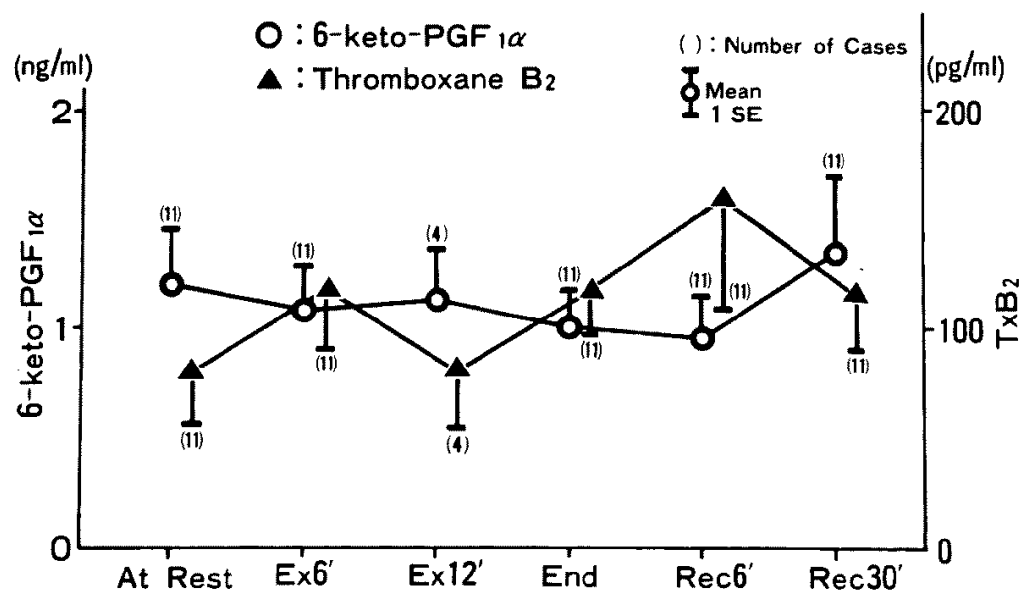

Fig. 3. Changes in plasma levels of thromboxane $B_{2}$ and 6-keto-prostaglandin $F_{1 \alpha}$.

\section{(2) Prostanoids}

Plasma thromboxane $\mathbf{B}_{2}$ levels showed a tendency to increase postexercise, while plasma 6-keto-prostaglandin $\mathrm{F}_{1 \alpha}$ levels to decrease with exercise (Fig. 3).

(3) Catecholamines

The plasma level of epinephrine had a tendency to increase with exercise, showing a significant elevation at 9 min of exercise, while that of norepinephrine significantly increased as the intensity of exercise was augmented (Fig. 4). The latter rose from $184( \pm 28) \mathrm{pg} / \mathrm{ml}$ at rest to $678( \pm 135) \mathrm{pg} / \mathrm{ml}$ at the end point of treadmill exercise $(p<0.005)$. Both plasma catecholamines returned to the pre-exercise level at 6 min after exercise. 


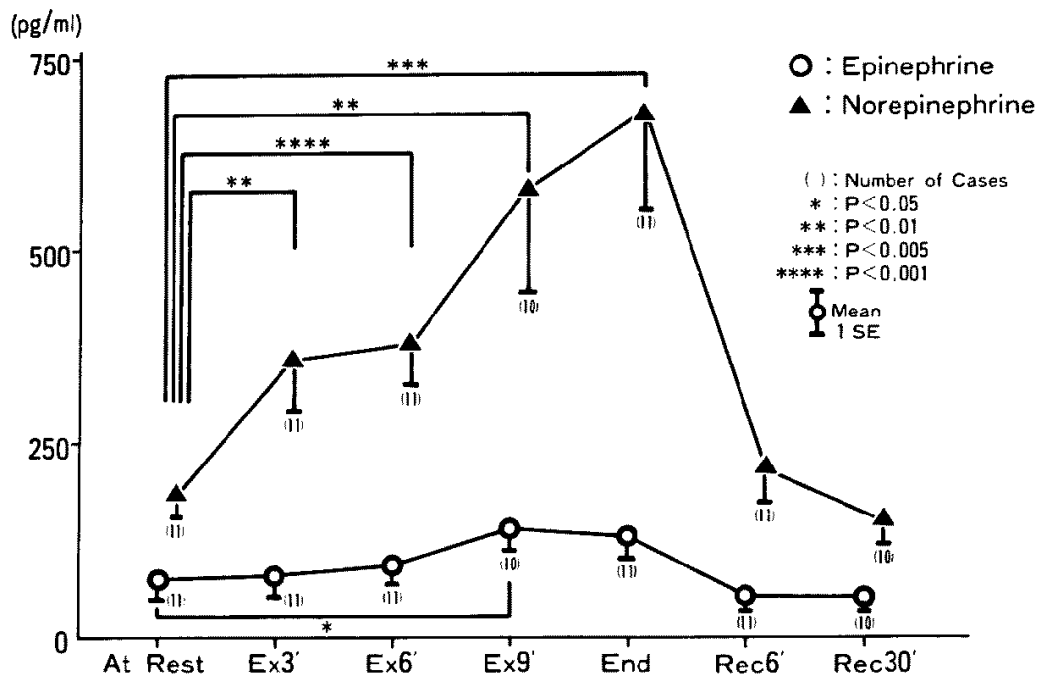

Fig. 4. Changes in plasma levels of epinephrine and norepinephrine.

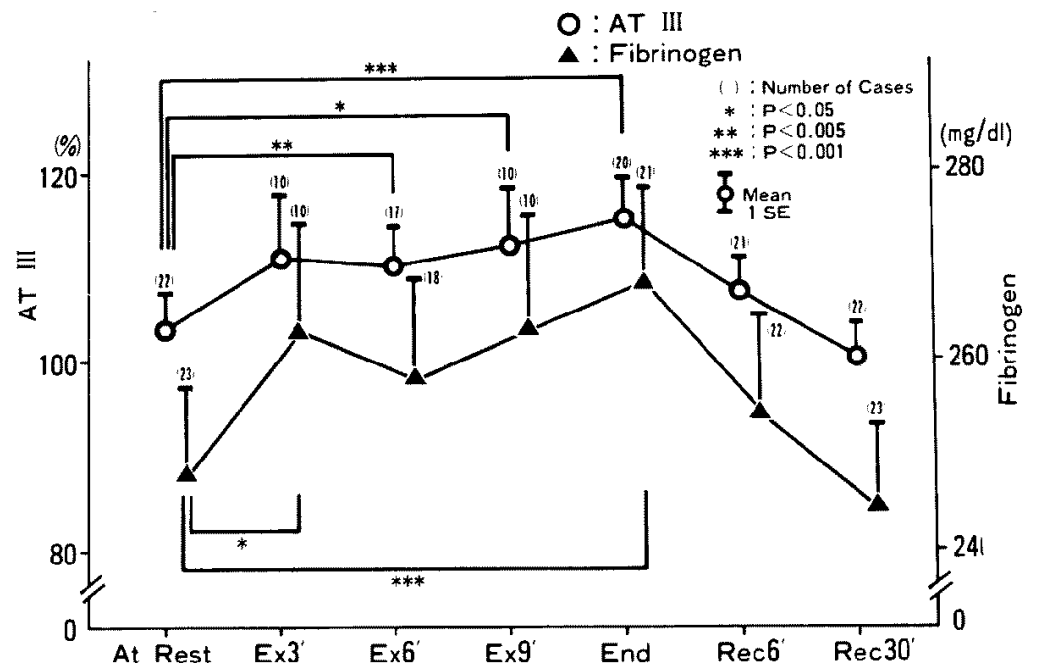

Fig. 5. Changes in antithrombin III activity and fibrinogen level.

\section{(4) Coagulating activities}

The plasma level of fibrinogen was significantly elevated as the intensity of exercise increased (Fig. 5). It was $248( \pm 9) \mathrm{mg} / \mathrm{ml}$ at rest and $268( \pm 10)$ $\mathrm{mg} / \mathrm{ml}$ immediately after exercise $(\mathrm{p}<0.005)$. The antithrombin III activity also significantly rose from $104( \pm 4) \%$ at rest to $115( \pm 4) \%$ at the end point of treadmill exercise $(\mathrm{p}<0.005)$. The factor VIII activity was significantly enhanced with exercise from $81( \pm 6) \%$ at rest to $103( \pm 6) \%$ at the end point of exercisc $(\mathrm{p}<0.01)$ (Fig. 6). The activity of factor IX showed 


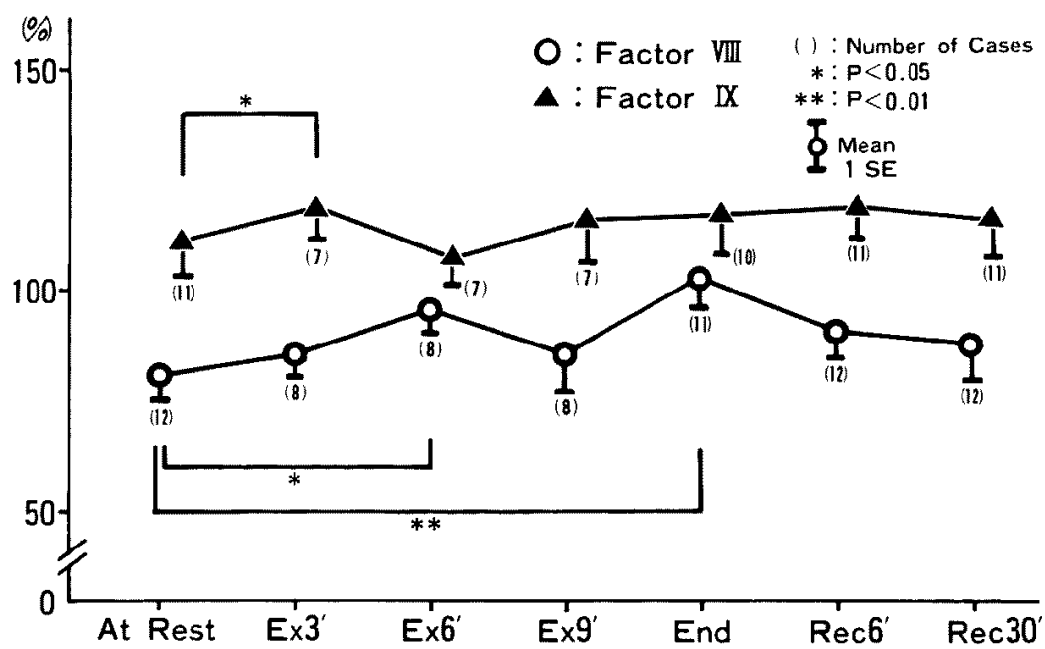

Fig. 6. Changes in activities of factors VIII and IX.

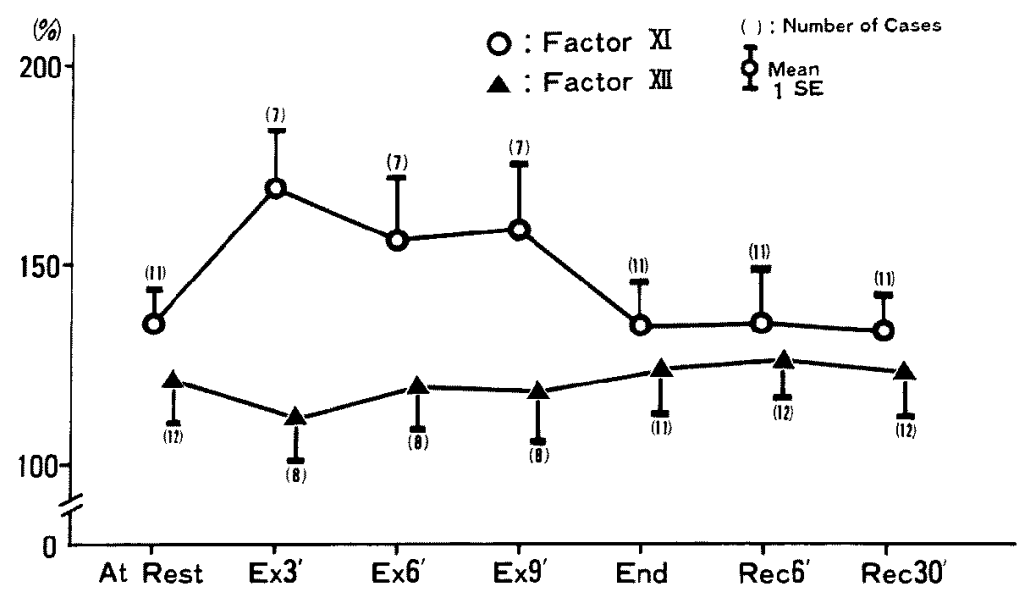

Fig. 7. Changes in activities of factors XI and XII.

a significant elevation only at 3 min of exercise, and that of factors XI and XII showed little changes with exercise (Fig. 7). In spite of the presence of significant exercise-induced changes in several coagulating factors, prothrombin time and partial thromboplastin time were not influenced by exercise (Fig. 8).

\section{Discussion}

It has been reported by many researchers that dynamic or isometric exercise influenced the balance among platelet functions, coagulating activities and fibrinolysis in normal subjects and also in patients with a tendency to 


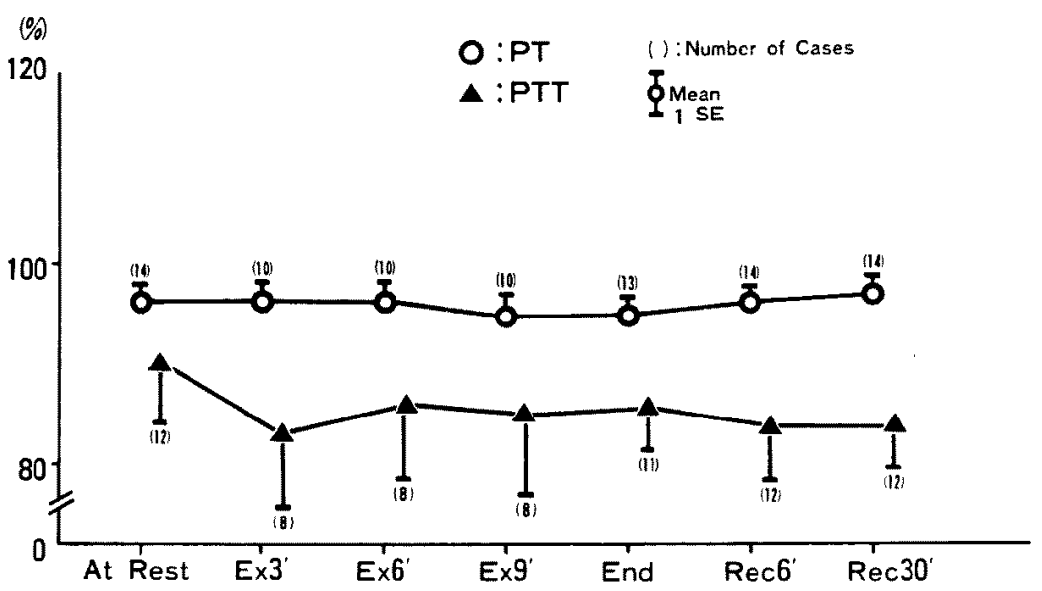

Fig. 8. Changes in prothrombin time and partial thromboplastin time.

thrombo-embolism. However, there still existed controversies on the effects of exercise to these hemostatic parameters. The difference in the results of previous studies seems to be due to difference in the type of intensity of exercise, or the method used for the measurement of platelet functions, coagulating activities and fibrinolysis.

In the present study, we investigated platelet functions in treadmill exercise from the viewpoints of platelet aggregation and platelet-related prostaglandins in normal men. The platelet sensitivity as well as the percent aggregation assessed by the O.D. method were studied with ADP of 0.5, 1, 2, and $4 \mu \mathrm{M}$. No significant changes were observed in these parameters and also in the plasma level of thromboxane $B_{2}$ and 6-keto-prostaglandin $\mathbf{F}_{1^{\alpha}}$ during and after treadmill exercise with the target heart rate of $85 \%$ of the predicted maximum heart rate. It was confirmed that platelet function was not influenced by dynamic leg exercise of moderate to high intensity. These results are in accordance with some ${ }^{3), 6), 31)}$ but not all ${ }^{4,5)}$ previous reports.

Yamazaki et al reported that in healthy volunteers there were no statistically significant changes in the percent ADP aggregation measured at 1, 3, 5, and 10 min after Master double two-step test. ${ }^{3)}$ Warlow et al reported a significant increase in the rate of the second phase of ADP- and epinephrineinduced aggregation both at 1 and 2 hours after strenous running for $15 \mathrm{~min}$ in healthy men. ${ }^{4}$ They also observed a highly significant increase in the mean platelet counts after exercise in both the citrated whole blood and PRP but no significant changes in platelet adhesion. On the other hand, Lee et al demonstrated a decreased platelet aggregation related to the level of exertion during and after multistage treadmill exercise in normal subjects and no rebound of platelet aggregation immediately after exercise. ${ }^{5)}$ In this report 
the platelet aggregation study was performed using $40 \mu \mathrm{M}$ of ADP which was much higher concentration of ADP than ours, after normalization of platelet count. In these reports platelet aggregation was studied by O.D. method as in the present study. Thus, the effects of dynamic leg exercise on platelet function are still controversial.

Recently, a new microscopical method for the assessment of platelet sensitivity to ADP-aggregation was devised by Sano and co-workers. ${ }^{6}$ ) This new method made it possible to assess platelet sensitivity without centrifugation, thus avoiding mechanical stress to platelets. It required only $0.8 \mathrm{ml}$ of blood and inexpensive equipment. They showed that platelet sensitivity did not change with isometric exercise in healthy subjects. Later, they also studied the effects of isometric exercise on plasma von Willebrand's titer and betathromboglobulin levels in normal subjects, confirming no significant changes in these parameters. ${ }^{31}$ However, the relationship between platelet aggregation and prostaglandins during exercise was not studied in the above reports.

In the present study, the platelet counts in PRP increased postexercise without a significant change in those in whole blood. There is a report that platelet counts increased in citrated whole blood and PRP following a short period of strenous physical exercise. ${ }^{4)}$ The increase was too large to be attributable to the small increase in hematocrit and occurred so rapidly that it was unlikely to be due to increased platelet production. Bennett revealed significantly elevated platelet counts following strenous exercise but no significant changes in them after mild exercise, suggesting that the increased counts of platelet may be due to their entry into the axial blood flow from the periphery of the vascular lumen. ${ }^{32}$ It was reported by Dawson et al that postexercise thrombocytosis could occur in splenectomized subjects. ${ }^{33)}$ From these reports including ours, it is suggested that there is an increased mobilization of platelets following strenous exercise, which will not, however, be induced by exercises of up to $85 \%$ of the predicted maximum heart rate. The observation in the present study that there was an increased count of platelets in PRP but not in whole blood, remains unanswered.

According to many reports, the plasma concentration of intrinsic catecholamines increases during exercise. ${ }^{12), 34)}$ Epinephrine has three effects on platelet aggregation, namely induction of both the first and second aggregation, and potentiation of ADP aggregation, ${ }^{35), 36)}$ while norepinephrine is less active than epinephrine on platelets. Elevated plasma levels of these substances is likely to enhance platelet aggregation. In the present study, plasma levels of epinephrine had a tendency to increase with exercise and those of norepinephrine significantly increased as the exercise intensity increased, without a significant change in ADP aggregation. From the results of our 
study, it seems that the increased amounts of catecholamines in blood during exercise might be too small to activate platelet aggregation.

In the present study, dynamic leg exercise of moderate to high intensity showed a tendency to elevate the plasma level of thromboxane $B_{2}$ and to decrease that of 6-keto-prostaglandin $F_{1^{\alpha}}$ in normal subjects, no significant changes being observed in platelet aggregation. Elevated plasma levels of thromboxane $B_{2}$ were found in both peripheral and coronary sinus blood in patients with angina pectoris and myocardial infarction, ${ }^{18), 20)}$ and lowered levels of circulating prostacyclin were found in patients with ischemic heart disease. ${ }^{37}$ These reports including others ${ }^{19)}$ suggested that an elevated level of thromboxane $A_{2}$ and a lowered level of prostacyclin take part in thrombus formation.

The present study showed that treadmill exercise of moderate to high intensity induced a significant elevation in the plasma epinephrine and fibrinogen concentration as well as in the plasma activity of factor VIII and antithrombin III in normal subjects. There are a lot of reports concerning the effects of exercise on coagulating activities. Most of the data supported the concept that clotting was potentiated by exercise. ${ }^{7,8)}$ A number of exerciserelated factors that would accelerate the clotting sequences included activation of the extrinsic pathways by release of tissue thromboplastin, ${ }^{9}$ increased coagulation with lactate accumulation, ${ }^{10)}$ and increased concentration of plasma proteins owing to hemoconcentration and of specific clotting factors (factors VIII, ${ }^{11)} \mathrm{V},{ }^{10)} \mathrm{VII},{ }^{13)} \mathrm{XII},{ }^{13)}$ and fibrinogen ${ }^{12)}$ ). Factor VIII is believed to be identified as a co-factor for platelet adhesion, ${ }^{38}$ ) therefore this substance specifically takes part in thrombus formation. Hawkey and coworkers demonstrated that epinephrine, factor VIII, and fibrinogen increased after exercise with a bicycle ergometer in normal subjects, and suggested that an exercise-induced increase in factor VIII was mediated via adrenergic stimulation. ${ }^{12)}$ The storing site of factor VIII is thought to be on vascular endothelial cells. ${ }^{39}$ Elevation of factor VIII and fibrinogen levels during exercise in the present study seems to promote blood coagulability.

Antithrombin III, and inhibitor of the enzymatic activity of thrombin, is one of the important factors that regulate coagulability. A high incidence of thrombosis was pointed out in patients with familial antithrombin III deficiency. ${ }^{40)}$ Therefore, a decreased antithrombin III activity tends to accelerate thrombo-embolism formation. However, the reports which studied the effects of exercise on this substance are very few. The present study showed an increase in antithrombin III, which seems to cancel the effects of the increased activity of factor VIII and the increased concentration of fibrinogen. As a result, prothrombin time and partial thromboplastin time 
were not influenced by exercise.

In conclusion, a treadmill exercise of moderate to high intensity produced significant increases in factor VIII, fibrinogen and norepinephrine as well as antithrombin III, without affecting the hemostatic and coagulating balance in normal subjects. Effects of treadmill exercise of moderate to high intensity on hemostasis and coagulation seem to be little in normal subjects.

\section{ACKNowledgment}

The authors express their gratitude to Prof. Itsuro Sobue, the First Department of Internal Medicine, School of Medicine, Nagoya University for his kind advice.

\section{REFERENCES}

1. Moure S, Friedman RJ, Spingal DP, Gauldie JJ, Blajchman MA, Roberts RS: Inhibition of injury induced thromboatherosclerotic lesions by antiplatelet serum in rabbits. Thrombos Haemostas 35: 70, 1976

2. Fuster V, Bowie EJW, Lewis JC, Fass DN, Owen CA, Brown AL: Resistance to arteriosclerosis in pigs with von Willebrand's disease. Spontaneous and high cholesterol diet-induced arteriosclerosis. J Clin Invest 61 : 722,1978

3. Yamazaki H, Kobayashi I, Shimamoto T: Enhancement of ADP-induced platelet aggregation by exercise test in coronary patients and its prevention by pyridinolcarbamate. Thromb Diath Haemorrh 24: 438, 1970

4. Warlow CP, Ogston D: Effect of exercise on platelet count, adhesion and aggregation. Acta Haemat 52: 47, 1974

5. Lee G, DeMaria A, Borhani NO, Giddens J, Kaku R, Flagg J, Amsterdam E, Mason DT: Exercise induced decreases in platelet aggregation: comparison of normals and coronary patients showing similar physical activity related effects. Clin Res 25:232A, 1977

6. Sano T, Motomiya T, Yamazaki H, Shimamoto T: Enhancement of platelet sensitivity to ADP-aggregation by isometric exercise in arteriosclerotic patients and its prevention. Thrombos Haemostas 37: 329, 1977

7. Schneider RA, Zangari VM: Variations in clotting time, relative viscosity, and other physiochemical properties of the blood accompanying physical and emotional stress in the normotensive and hypertensive subjects. Psychosom Med 13: 289, 1951

8. Mills CA, Necheles $\mathrm{H}$ : Variations in the coagulability of the blood normally and after food ingestion. Clin J Physiol 2: 19, 1928

9. Fowler WM, Chowdhury SR, Pearson CM, Gardner G, Bratton R: Changes in serum enzyme levels after exercise in trained and untrained subjects. J Appl Physiol 17: 943, 1962

10. Corwell JW, Houston B: Effects of acidity on blood coagulation. Am J Physiol 201: 379, 1961

11. Rizza CR: Effect of exercise on the level of antihaemophilic globulin in human blood. J Physiol 156: 128, 1961

12. Hawkey CM, Britton BJ, Wood WG, Peele MM, Irving MH: Changes in blood catecholamine levels and blood coagulation and fibrinolytic activity in response to graded exercise in man. Br J Haematol 29: 377, 1975

13. Iatridis SG, Ferguson JH: Effect of physical exercise on blood clotting and fibrinolysis. J Appl Physiol 18: 337, 1963 
14. Yamazaki H, Sano T, Odakura T, Takeuchi $\mathrm{K}$, Shimamoto $\mathrm{T}$ : Electrocardiographic and hematological changes by exercise test in coronary patients and pyridinolcarbamate pretreatment. A double blind crossover trial. Am Heart J 79: 640, 1970

15. Hamberg M, Svensson J, Samuelsson B: Thromboxanes, a new group of biologically active compounds derived from prostaglandin endoperoxides. Proc Nato Acad Sci USA 72: 2994, 1975

16. Moncada S, Gryglewski R, Bunting S, Vane JR: An enzyme isolated from arteries transforms prostaglandin endoperoxides to an unstable substance that inhibits platelet aggregation. Nature 263: 663, 1976

17. Gryglewski RJ, Bunting S, Moncada S, Roderick JF, Vane JR: Arterial walls are protected against deposition of platelet thrombi by a substance (prostaglandin $\mathrm{X}$ ) which they make from prostaglandin endoperoxides. Prostaglandins 12: 685, 1976

18. Tada M, Kuzuya $T$, Inoue $M$, Kodama $K$, Fukushima $M$, Abe $H$ : Significance of thromboxane $A_{2}$ in myocardial ischemia in patients with coronary artery disease. Advances in Myocardiology 2: 397, 1980

19. Lewy RI, Wiener L, Smith JB, Walinsky P, Silver MJ, Saia J: Comparison of plasma concentrations of thromboxane $B_{2}$ in Prinzmental's variant angina and classical angina pectoris. Clin Cardiol 2: 404, 1979

20. Auke CB, Alexander GG, Turpie MB, Rodney W, Butt RT, Raymond V, Johnston MB, Edward G: Platelet release and thromboxane synthesis in symptomatic coronary artery disease. Circulation 66: 327, 1982

21. Sotobata I, Sino T, Kondo T, Tsuzuki J: Work intensities of different modes of exercise testings in clinical use. Jpn Circulat J 43: 161, 1979

22. Born GVR: Aggregation of blood platelets by adenosine diphosphate and its reversal. Nature 194: 927, 1962

23. O'Brien JR: Platelet aggregation, Part 2. Some results from a new method of study. J Clin Path 15: 452, 1962

24. Green K, Hamberg M, Samuelsson B, Frolich JC: Extraction and chromatographic procedures for purification of prostaglandins, thromboxanes, prostacycline, and their metabolites. Advances in Prostaglandin and Thromboxane Research 5: 15, 1978

25. Euler US, Floding I: A fluorimetric micromethod for differential estimation of adrenaline and noradrenaline. Acta Physiol Scand 33 (Suppl 118): 45, 1955

26. Mori K: Analysis of catecholamines by high speed liquid chromatography (part II). The effect of mobile phase and column temperature on capacity factor. Jap J Ind Health 16: 494, 1974

27. Hardisty RM, Macpherson JC: A one stage factor VIII (antihemophilic globulin) assay and its use on venous and capillary plasma. Thromb Diath Haemorrh 7: 215, 1962

28. Rapaport SI, Ames SB: Relation between levels of plasma thromboplastin component (PTC) and prothrombin times by the $\mathrm{P} \& \mathrm{P}$ and quick method in patients receiving warfarin. New Engl J Med 267: 125, 1962

29. Horowitz NI, Wilcox WP, Fujimoto MM: Assay of plasma thromboplastin antecedent (PTA) with artificially depleted normal plasma. Blood 22: 35, 1963

30. Loeliger EA, Hensen A: Coagulation studies in a case of Haegeman trait. Thromb Diath Haemorrh 5: 187, 1960

31. Sano T, Motomiya T, Yamazaki H: Platelet release reaction in vivo in patients with ischemic heart disease after isometric exercise and its prevention with dipyridamole. Thrombos Haemostas 42: 1589, 1979

32. Bennett PN: Effect of physical exercise on platelet adhesiveness. Scand J Haemat 9: 138, 1972

33. Dawson AA, Ogston D: Exercise-induced thrombocytosis. Acta Haemat 42: 241, 1969

34. Kotchen TA, Hartly LI, Rice TW, Mougey EH, Jones LG, Mason JW: Renin, norepinephrine and epinephrine responses to graded exercise. J Appl Physiol 31 : 178, 1971 
35. O'Brien JR: A comparison of platelet aggregation produced by seven compounds and a comparison of their inhibitors. J Clin Path 17: 275, 1964

36. Mils DCB, Roberts GCK: Effects of adrenaline on human blood platelets. J Physiol 193: 443,1967

37. Masotti G, Poggesi L, Galanti G, Castellani S, Meri Serneri GG: Low blood levels of circulating prostacyclin and reduced prostacyclin production by vessel wall in patients with ischemic heart disease. Florence International Meetings on Myocardial Infarction, Proceedings $\mathrm{p} 379,1979$

38. Tschopp TB, Weiss HJ, Baumgarter HR: Decreased adhesion of platelets to subendothelium in von Willebrand's disease. J Lab Clin Med 83: 239, 1974

39. Bloom AL, Giddings JC, Wilks CJ: Factor VIII on the vascular intima : possible importance in haemostasis and thrombosis. Nature: New Biology 241 : 217, 1973

40. Kaulla E, Kaulla KN: Deficiency of antithrombin III activity associated with hereditary thrombosis tendency. J Med 3: 349, 1972 